\title{
QUANTITATIVE CORRELATION OF SALIVARY STREPTOCOCCUS MUTANS COUNT AMONGST SIBLINGS AND THEIR MOTHERS
}

\author{
Paramdeep Singh ${ }^{1}$, Avninder Kaur ${ }^{2}$, Neerja Kakkar ${ }^{3}$, Manjeet Kaur ${ }^{4}$, Shivesh Acharya ${ }^{5}$ \\ ${ }^{1}$ Senior Lecturer, Pediatric and Preventive Dentistry, Laxmi Bai Institute of Dental Sciences, Punjab, India \\ ${ }^{2}$ Professor \& Head, Pediatric and Preventive Dentistry, Bhojia Dental College and Hospital, Himachal Pradesh, India \\ ${ }^{3}$ Professor, Microbiology, BRS Institute of Medical Sciences, Haryana, India \\ ${ }^{4}$ Professor, BRS Institute of Medical Sciences, Haryana, India \\ ${ }^{5}$ Reader, Pediatric and Preventive Dentistry, Bhojia Dental College and Hospital, Himachal Pradesh, India
}

Corresponding Author: Avninder Kaur E-mail:

avninder21@yahoo.com Received: $2^{\text {nd }}$ May 2017 Accepted: $15^{\text {th }}$ August 2017 Online: $20^{\text {th }}$ September 2017

\begin{abstract}
Aim: The present study was planned to analyze quantitative correlation of salivary Streptococcus Mutans (S. Mutans) in siblings and their mothers. Materials and Methods: Quantitative analysis of S. Mutans in saliva was performed using Dentocult SM strip mutans kit (Orion Diagnostica, Helsinki, Finland) in closely related members of the family i.e. siblings along with their mothers. Results: $S$. Mutans count between the siblings showed positive correlation which was statistically highly significant. The younger childrens ${ }^{\prime} S$. Mutans count was very highly correlated $\left(r_{s}=0.711\right)$ with the mothers' as compared to that of the older children $\left(r_{s}=0.412\right)$. The $S$. Mutans count was found to be associated with caries score and was statistically significant. A statistically highly significant positive association was also found with the plaque score. Conclusion: The correlation between the $S$. Mutans count of related individuals has been reaffirmed. $S$. Mutans is positively associated with dental caries.
\end{abstract}

Key words: Streptococcus Mutans, S. Mutans, siblings, horizontal transmission, quantitative analysis.

\section{INTRODUCTION}

Streptococcus Mutans (S. Mutans) was first described by J Kilian Clarke (1924) and is one of primary factors causing dental caries. This microorganism metabolizes sucrose in an anaerobic environment to produce lactic acid and provides an acidic environment for dental caries initiation. It thrives under acidic conditions and becomes the dominant bacterium in cultures with permanently reduced $\mathrm{pH}$. It starts to colonize an infant's mouth soon after birth. ${ }^{2}$ Vertical transmission of $S$. Mutans from mother to child is a well know fact, and a discrete window of infectivity exists around 18 months of age., Later on microbial colonization increases as more tooth surfaces are available for flourishing of the microbes. Maternal salivary level of S. Mutans greater than $10^{6} \mathrm{CFU} / \mathrm{ml}$ has been proposed as a risk factor for vertical transmission. ${ }^{4,5}$ Thus, mothers who share food, drinks, utensils, toothbrushes and other items with their children have the highest risk of transmitting S. Mutans to their offsprings. ${ }^{6} \quad$ The current reports point out that vertical transmission is not the only vector by which $S$. Mutans are perpetuated in humans. ${ }^{6}$ Numerous studies have investigated the horizontal or child to child transmission of S. Mutans. Frequent close contacts with others seem to be sufficient to transmit S. Mutans. Hence, the present study was conducted to evaluate $S$. Mutans count in siblings and their mothers along with various causal factors. 


\section{MATERIALS AND METHODS}

Ninety subjects constituted the total sample size. Thirty mothers along with their 2 children belonging to age range of 6-10 years were included in the study. Children were divided into younger and the older child based on their birth order. The study was approved by Ethics Committee of B.R.S. Institute of Medical Sciences. Research has been conducted in full accordance with the World Medical Association Declaration of Helsinki. ${ }^{7}$ Selection of the sample was done from patients visiting the outpatient Department of Paediatric \& Preventive Dentistry, B.R.S. Institute of Medical Sciences, Vill. Sultanpur (Panchkula), Haryana, India and children studying in the nearby schools. An inclusion criterion was healthy children and the mothers who were the primary caregivers to the selected children. The subjects who had received any antibiotic medication in the past one month, received prophylaxis, topical fluoride application and use of mouth wash in past 3 weeks, allergic to paraffin wax and undergoing orthodontic treatment were excluded from the study.

\section{Clinical examination}

Written consent by translating in local language was obtained after explaining the nature of the study from the parents of selected children and consent procedure was approved by Ethical committee of the Institute. Clinical examination was done by seating the patient in a dental chair. Caries was recorded according to WHO criteria $(1997)^{8}$ and lesions at $\mathrm{D}_{2}$ and $\mathrm{D}_{3}$ levels were included in the study. The plaque score was recorded as per Silness and Loe (1964) ${ }^{9}$ Index. Findings were recorded on specially designed proforma for mothers and children, separately. The subjects were given instructions not to eat, brush or use mouthwash 2 hours before sample collection as it would interfere with the actual count of $S$. Mutans in the saliva. Subjects were recalled next day for saliva sampling. Twenty four hour diet recall was also obtained. Not more than three mothers along with their 6 children were sampled in one day.

\section{Quantitative analysis of S. Mutans:}

The culture medium vials were taken out from the refrigerator 1 hour prior to saliva collection. Two bacitracin discs were added to the medium 15 minutes before sample collection using sterile tweezer and then the medium was gently shaken for activation. Mothers were told to wipe off their lipstick before sample collection as it would have stained the strip. The subjects were told to chew on the paraffin wax pellet provided in the kit for 1 minute and asked to use all teeth during chewing in order to maximize the transfer of $S$. Mutans adhered to the teeth into the saliva. The paraffin pellet was then removed from the mouth and disposed off properly. They were then told to swallow the excess of saliva after 1 minute of chewing. The rough surface of the strip provided in the kit for saliva collection was rubbed 10 times gently against the tongue of the subject which ensured the transfer of $S$. Mutans onto the strip. The strip was then withdrawn from the mouth with lips gently closed to remove the excess saliva.

\section{Microbial culturing:}

The strip was immediately transferred to the selective culture vial. It was attached to a groove provided inside the cap of the vial to allow its easy removal after culturing and was then positioned in the special stand provided with the kit and was transferred to the incubator within $1 \mathrm{~h}$. Before putting the vial in the incubator, the cap was opened one quarter to allow elimination of the gases resulting from yeast growth. Strict asepsis was maintained at all levels to avoid any sort of contamination. The vial was incubated at $37^{\circ}$ for $48 \mathrm{~h}$. In case of no growth, it was further incubated for next $48 \mathrm{~h}$. After incubation, the strips were visually compared for colony density of S. Mutans with the chart provided with the kit as shown in figures 1, 2, 3 and 4 . The chart contained 4 pictures of strips each 
having different scores of $S$. Mutans count for comparison.

\section{Statistical Analysis:}

Statistical analysis was performed on the software SPSS version 13.0. Spearman's Rank correlation was used to assess the correlation between the S. Mutans count of mother with her children and amongst the siblings as well as between S. Mutans count and brushing frequency. Multivariate regression analysis of deft/DMFT, $S$. Mutans count, plaque score, use of fluoridated dentifrice and in-between meals sugar exposures was done.

\section{RESULTS}

Out of 30 mothers examined, $76.6 \%$ were found to be colonized with $S$. Mutans. Scores ' 0 ', 1, 2 and 3 were observed in $23.3 \%, 20 \%, 33.3 \%$ and $23.3 \%$ mothers, respectively. In younger children, out of 30, 60\% were found to harbour S. Mutans; $40 \%$ had score '0'; 13.3\% had ' 1 '; $26.7 \%$ had'2' and 20\% had score ' 3 '. In older children out of $30,73.3 \%$ were found to have $S$. Mutans; thus 26.7\% had score ' 0 '; $26.6 \%$ had ' 1 '; $20 \%$ had ' 2 ' and $26.6 \%$ had score ' 3 '. Nineteen subjects from the sample were free from caries i.e. $21.1 \%$.

Out of 30 mothers examined, 2 had DMFT score 0 and highest score found was 9 . In younger children, highest deft score found was 9 in one child only, score 0 was found in 9 children (30\%). Eight subjects in the older child group were caries free $(26.7 \%)$ and highest deft score was 11 and was found in only one child. The mean DMFT score of mothers was $3.63(\mathrm{SD} \pm 2.38)$. Mean of deft scores of younger and older children were $2.13(\mathrm{SD} \pm 2.30) \& 2.9(\mathrm{SD} \pm 2.80)$; respectively. Five out of 30 sibling pairs shared their toothbrushes and positive correlation was observed between $S$. Mutans count of these siblings which was statistically highly significant $\left(r_{s}=0.968, p=0.007\right.$; respectively $)$.

\section{DISCUSSION}

S. Mutans count of siblings and their mothers was evaluated with the Dentocult SM "Strip mutans" kit (Orion Diagnostica, Helsinki, Finland) with sensitivity and specificity of $98 \%$ and $85 \%$, respectively. Subjects selected were from lower/Upper lower socio-economic status (IV) which was ascertained based on their family income and mother's level of education (below metric). ${ }^{10}$ The age group of 6-10 years was selected because the second window of infectivity exists in this age range. ${ }^{11}$ The presence of $S$. Mutans was evidenced by dark blue to light blue raised colonies on rough surface of the strip. Colonies suspended in the culture broth were excluded from the study.

In the present study $56.6 \%$ mothers had a high count of $S$. Mutans (scores $2 \& 3$ ) in their saliva which increase the chances of transmission. Score 2 and 3 of S. Mutans was found in $46.6 \%$ siblings. Mother to child transmission of S. Mutans was first reported by Berkowitz in 1975. ${ }^{12}$ It was evidenced from several studies showing that isolates of S. Mutans harboured by mothers and their children exhibit identical plasmid or chromosomal DNA patterns. ${ }^{12,13}$ Several studies have indicated that the mutans streptococci are transmitted vertically, along familial lines, from mother to child. ${ }^{12-20}$ The present study evidenced that the younger child's S. Mutans count was very highly correlated $\left(r_{s}=0.711\right)$ with the mother's count as compared to that of the older child $\left(r_{s}=0.412\right)$ as shown in Table 1. The high

Table 1: Correlation of S. Mutans count of mothers with that of younger and older children

\begin{tabular}{|l|l|c|c|}
\hline & & $\begin{array}{l}\text { S. } \text { Mutans } \\
\text { count of } \\
\text { younger } \\
\text { children }\end{array}$ & $\begin{array}{l}\text { S. Mutans } \\
\text { count of } \\
\text { older } \\
\text { children }\end{array}$ \\
\hline \multirow{2}{*}{$\begin{array}{l}\text { S. } \text { Mutans } \\
\text { count of } \\
\text { mothers }\end{array}$} & $\begin{array}{l}\text { Spearman's } \\
\text { Rho }\left(\mathbf{r}_{\mathbf{s}}\right)\end{array}$ & 0.711 & 0.412 \\
\cline { 2 - 4 } & $\mathbf{p}-$ value & 0.000 & 0.024 \\
\cline { 2 - 4 } & $\mathbf{N}$ & 30 & 30 \\
\hline \multirow{2}{*}{$\begin{array}{l}\text { S. } \text { Mutans } \\
\text { count of } \\
\text { mothers } \\
\text { who shared } \\
\text { eatables }\end{array}$} & $\begin{array}{l}\text { Spearman's } \\
\text { Rho }\left(\mathbf{r}_{\mathbf{s}}\right)\end{array}$ & 0.708 & 0.418 \\
\cline { 2 - 4 } & $\mathbf{p}-\mathbf{v a l u e}$ & 0.000 & 0.024 \\
\cline { 2 - 4 } & $\mathbf{N}$ & 29 & 29 \\
\hline
\end{tabular}

correlation of $S$. Mutans count might have existed because of higher frequency of sharing with the younger child as compared to the older child. Antony \& 
Munshi $^{21}$ also reported quantitative correlation between the number of CFU $/ \mathrm{ml}$ of $S$. Mutans in the mother and her second child only. Many authors have concluded that there is a clear correlation of the $S$. Mutans levels between mother and her children. ${ }^{17,21}$ On the contrary, Caufield et al (1993) ${ }^{2}$ and Aaltonen et al (1994) ${ }^{19}$ found that mothers' and childrens' $S$. Mutans levels were not significantly associated.

Sharing of eatables or utensils is a major mode of transmission of bacteria. Out of 30 sibling pairs, 29 were found to be sharing eatables with their mothers. Twenty nine sibling pairs who shared eatables with their mothers (Table 1) had a significant positive correlation of S. Mutans count with their mothers. However, the reported maternal transmission rates range from $24 \%$ to $100 \%{ }^{22-23}$ This wide range in transmission rates clearly demonstrates that mothers are not the only source of $S$. Mutans transmission, other individuals who are potential sources, such as siblings, grandparents, and non family caretakers who share responsibility for caring for the child might be the reason. In the present study, S. Mutans count of siblings was highly correlated $\left(\mathrm{r}_{\mathrm{s}}=0.470\right.$; Table 2$)$ which indicated possibility of horizontal transmission between the siblings. Various authors have reported transmission between family members. Domejean $\mathrm{S}$ $(2010)^{2]}$ reported horizontal transmission in non-related individuals. Horizontal transmission among nursery cohorts with prolonged exposure to an environment that favours the spread of infectious agents was reported by Mattos-Graner et al (2001). ${ }^{25}$ In the present study, all 29 sibling pairs who shared eatables with their mothers, also shared eatables with each other and demonstrated a significant positive correlation $\left(r_{s}=0.447\right.$; Table 2) between their $S$. Mutans count. All the subjects were from low socio-economic status and the financial constraints might have resulted in the children sharing utensils and eatables which might be the reason for a significant positive correlation of their S. Mutans.
Table 2: Correlation of S. Mutans count between the siblings

\begin{tabular}{|c|c|c|}
\hline & & $\begin{array}{l}\text { S. Mutans } \\
\text { count of older } \\
\text { children }\end{array}$ \\
\hline \multirow{3}{*}{$\begin{array}{l}\text { S. Mutans count } \\
\text { of younger } \\
\text { children }\end{array}$} & $\begin{array}{l}\text { Spearman's } \\
\text { Rho }\left(r_{s}\right)\end{array}$ & 0.470 \\
\hline & $p$-value & 0.009 \\
\hline & $\mathbf{N}$ & 30 \\
\hline \multirow{3}{*}{$\begin{array}{l}\text { S. Mutans count } \\
\text { of younger } \\
\text { children who } \\
\text { shared eatables }\end{array}$} & $\begin{array}{l}\text { Spearman's } \\
\text { Rho }\left(r_{s}\right)\end{array}$ & 0.447 \\
\hline & $p$-value & 0.015 \\
\hline & $\mathbf{N}$ & 29 \\
\hline
\end{tabular}

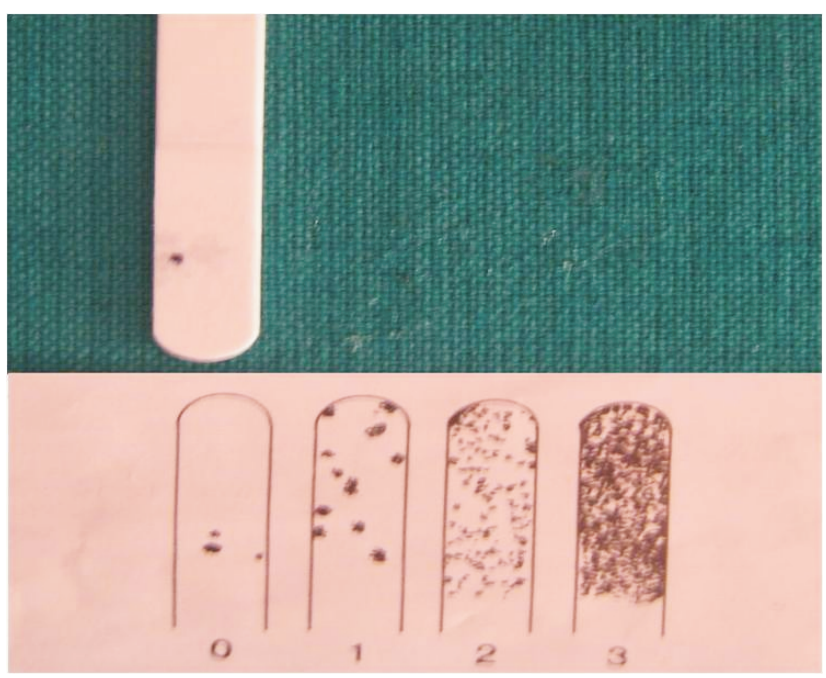

Figure 1: Score $0 \quad(<10,000 \mathrm{CFU} / \mathrm{ml})$

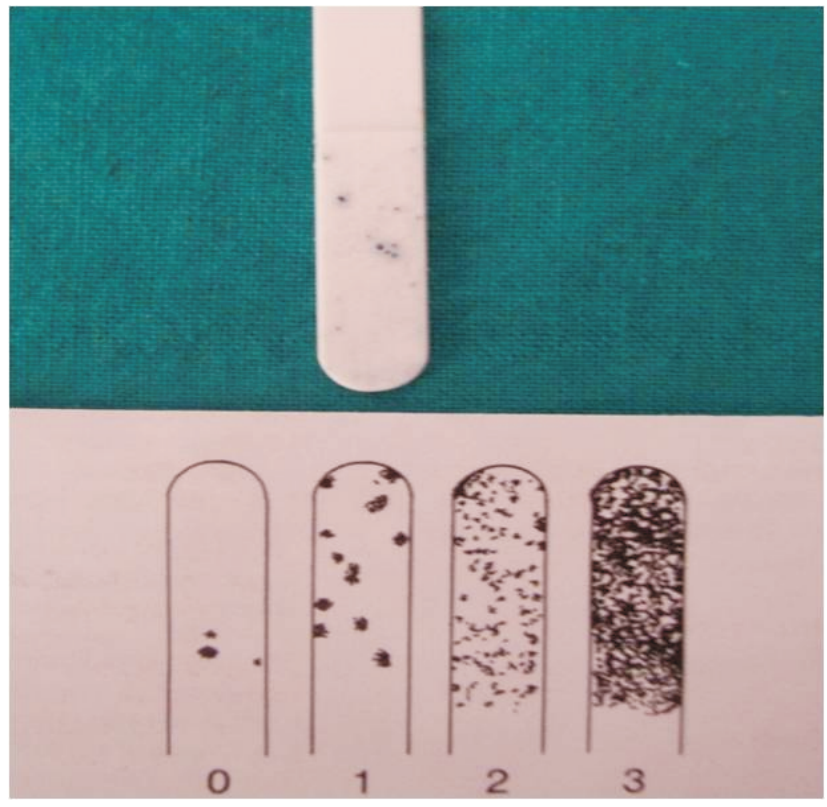

Figure 2: Score $1(<100,000 \mathrm{CFU} / \mathrm{ml})$ 
Vol. 5 (II) 2017 Dental Journal of Advance Studies

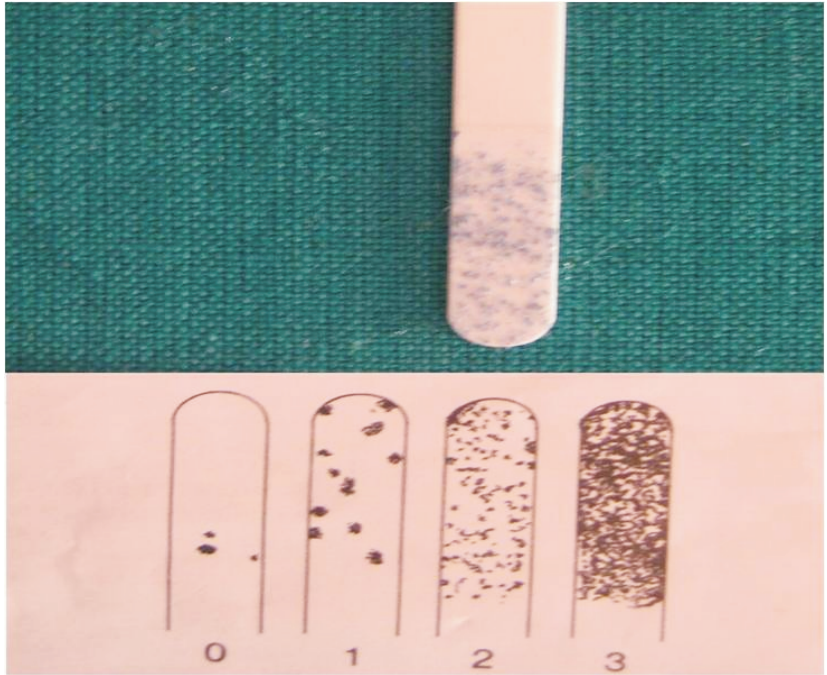

Figure 3: Score $2(100,000-10,00,000 \mathrm{CFU} / \mathrm{ml})$

S. Mutans can be transferred readily when a toothbrush is shared between 2 persons increasing the risk of dental caries. ${ }^{26}$ Five out of 30 sibling pairs also shared their toothbrushes. The $S$. Mutans count of these 5 sibling pairs showed a very high positive correlation $\left(r_{s}=0.968\right)$. Van Houte \& Green $(1974)^{27}$ pointed out that successful transmission of bacteria between human hosts is complex and depends on a variety of interrelated factors, including bacterial affinity to potential colonization sites and number of infecting bacterial cells available for attachment. The vehicle could be the domestic objects contaminated with saliva, such as spoons or toothbrushes. Warren DP et $\mathrm{al}^{28}$ have shown that contaminated toothbrushes harbour and transmit viruses and bacteria. They found that toothpaste use reduces the residual microbial contamination as in our study, An inverse relationship existed between brushing frequency and $S$. Mutans count (Table 3).

S. Mutans is strongly associated with human dental caries and has been supported by many epidemiological studies. ${ }^{18,21}$ In the present study, multivariate regression analysis was done in which caries score was taken as dependent variable (Table 4) and independent variables were S. Mutans count, plaque score, use of fluoridated dentifrice and number of sugar exposures. The regression analysis of the
Table 3: Correlation between brushing frequency and $S$. Mutans count of mothers, younger and older children

\begin{tabular}{|l|l|l|l|l|}
\hline & & $\begin{array}{l}\text { S. Mutans } \\
\text { count of } \\
\text { mothers }\end{array}$ & $\begin{array}{l}\text { S. Mutans } \\
\text { count of } \\
\text { younger } \\
\text { children }\end{array}$ & $\begin{array}{l}\text { S. Mutans } \\
\text { count of } \\
\text { older } \\
\text { children }\end{array}$ \\
\hline \multirow{2}{*}{$\begin{array}{l}\text { Brushing } \\
\text { Frequency }\end{array}$} & $\begin{array}{l}\text { Spearman's } \\
\left.\text { Rho(r } \text { r }_{\mathbf{s}}\right)\end{array}$ & -0.381 & -0.214 & -0.145 \\
\cline { 2 - 5 } & $\mathbf{p}$ - value & 0.038 & 0.257 & 0.444 \\
\cline { 2 - 5 } & $\mathbf{N}$ & 30 & 30 & 30 \\
\hline
\end{tabular}

Table 4: Multivariate regression analysis for carious score of mothers and siblings

\begin{tabular}{|c|l|l|l|l|l|}
\hline $\begin{array}{c}\text { Dependent } \\
\text { variable: } \\
\text { Caries } \\
\text { Score }\end{array}$ & & $\begin{array}{l}\text { S. } \text { Mutans } \\
\text { count }\end{array}$ & $\begin{array}{l}\text { Plaque } \\
\text { score }\end{array}$ & $\begin{array}{l}\text { Fluori- } \\
\text { dated } \\
\text { dentifrice }\end{array}$ & $\begin{array}{l}\text { Sugar } \\
\text { exposures }\end{array}$ \\
\hline \multirow{2}{*}{ Mothers } & $\mathrm{t}$ - value & 4.568 & 1.473 & -0.134 & 0.546 \\
\cline { 2 - 6 } & $\mathrm{p}$-value & 0.000 & 0.153 & 0.895 & 0.590 \\
\hline $\begin{array}{c}\text { Younger } \\
\text { children }\end{array}$ & $\mathrm{t}$ - value & 2.725 & 2.085 & -0.055 & 1.601 \\
\cline { 2 - 6 } & $\mathrm{p}$-value & 0.012 & 0.047 & 0.956 & 0.112 \\
\hline \multirow{2}{*}{$\begin{array}{c}\text { Older } \\
\text { children }\end{array}$} & $\mathrm{t}$ - value & 2.414 & 1.433 & -1.620 & 1.600 \\
\cline { 2 - 6 } & $\mathrm{p}$-value & 0.023 & 0.164 & 0.118 & 0.122 \\
\hline
\end{tabular}

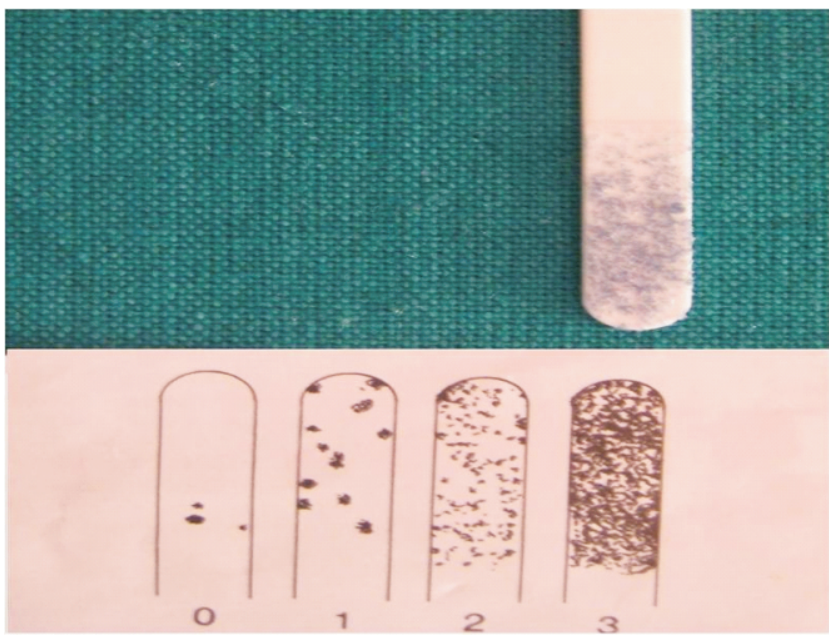

Figure 4 : Score $3(>10,00,000 \mathrm{CFU} / \mathrm{ml})$

mother found that S. Mutans count was positively associated with mothers' caries score and was statistically significant. Plaque score and number of sugar exposures were also positively associated but statistically insignificant and use of fluoridated 
dentifrice was negatively associated and it was also statistically insignificant. In younger children, both S. Mutans count and plaque score were statistically significant and positively associated with caries score, whereas, use of fluoridated dentifrice and number of sugar exposures were statistically insignificant. In older children, only S. Mutans count was statistically significant and positively associated and plaque scores, use of fluoridated dentifrice and number of sugar exposures were statistically insignificant. This demonstrates the infectious nature of dental caries. Very few studies like those on Danish preschool children and British school children; however reported no significant relationship between $S$. Mutans and the initiation of dental caries. ${ }^{29-30}$

When $S$. Mutans count was taken as dependent variable (Table 5) and caries score, plaque score, use of fluoridated dentifrice and number of sugar exposures as independent variable, it was seen that in mothers' $S$.

Table 5: Multivariate regression analysis for S. Mutans count of mothers and siblings

\begin{tabular}{|l|l|l|l|l|l|}
\hline $\begin{array}{l}\text { Dependent } \\
\text { variable: } \\
\text { S. Mutans } \\
\text { count }\end{array}$ & & $\begin{array}{l}\text { Caries } \\
\text { Score }\end{array}$ & $\begin{array}{l}\text { Plaque } \\
\text { score }\end{array}$ & $\begin{array}{l}\text { Fluoridated } \\
\text { dentifrice }\end{array}$ & $\begin{array}{l}\text { Sugar } \\
\text { exposures }\end{array}$ \\
\hline \multirow{2}{*}{ Mothers } & t-value & 4.568 & 1.740 & -0.694 & 0.112 \\
\cline { 2 - 6 } & p-value & 0.000 & 0.094 & 0.494 & 0.912 \\
\hline $\begin{array}{l}\text { Younger } \\
\text { children }\end{array}$ & t-value & 2.725 & 1.549 & -0.297 & 0.689 \\
\cline { 2 - 6 } & p-value & 0.012 & 0.134 & 0.769 & 0.497 \\
\hline \multirow{2}{*}{$\begin{array}{l}\text { Older } \\
\text { children }\end{array}$} & t-value & 2.414 & 2.838 & -1.801 & 1.216 \\
\cline { 2 - 6 } & p-value & 0.023 & 0.009 & 0.084 & 0.235 \\
\hline
\end{tabular}

Mutans count was very highly associated with caries as well as other factors like plaque and number of sugar exposures but were statistically insignificant. The use of fluoridated dentifrice was negatively associated with S. Mutans count but was statistically non significant. In younger children, it was only significantly associated with caries score, while plaque scores, use of fluoridated dentifrice and number of sugar exposures were statistically insignificant. In older children, it was statistically significant and positively associated with caries score and had highly significant association with plaque score but no statistically significant association was found with the use of fluoridated dentifrice and number of sugar exposures.

\section{CONCLUSION}

In the present study, quantitative analysis of $S$. Mutans showed positive correlation between mothers and their children. It showed the possibility of vertical and as well as horizontal transmission but it could not be proved whether this actually happened as the study lacked in procedures which prove homology of genotypes of $S$. Mutans between mothers and their children and also between siblings. In spite of these drawbacks, the conclusion drawn from the present study reinforces their certainty that S. Mutans is closely associated with dental caries. Also the correlation between the $S$. Mutans counts of related individuals has again been affirmed. Moreover, the results of the study once again call for the need for education and awareness of low socioeconomic strata where oral health measures still remains one of the most neglected aspect of general health especially in developing nations like India.

\section{REFERENCES}

1. Kilian Clarke J. On the bacterial factor in the aetiology of dental caries. Br J Exp Pathol 1924 Jun; 5(3):141-7.

2. Caufield PW, Cutter GR, Dasanayake AP. Initial acquisition of mutans streptococci by infants: evidence of a discrete window of infectivity. J Dent Res 1993; 72(1): 37-45.

3. Li Y, Caufield PW. The fidelity of initial acquisition of mutans streptococci by infants from their mothers. J Dent Res 1995; 74: 681-5.

4. Kohler B, Bratthall D. Intrafamilial levels of Streptococcus mutans and some aspects of the bacterial transmission. Scand J Dent Res 1978; 86(1): 35-42.

5. Van Houte J, Yanover L, Brecher S. Relationship of levels of the bacterium Streptococcus mutans in saliva of children and their parents. Arch Oral Biol 1981;26(5): 381-6.

6. Berkowitz RJ. Mutans Streptococci: Acquisition and Transmission. Pediatr Dent 2006; 28(2): 106-9.

7. World Medical Association Declaration of Helsinki - Ethical principles for medical research involving human subjects. WMA General Assembly, Fortaleza, Brazil; October 2013. World Med J. 2013 Oct; 59(5):199-202. 
8. World Health Organization. Oral health surveys - Basic Methods. 1997, $4^{\text {th }}$ Edition, Geneva.

9. Silness J, Loe H. Periodontal Disease in Pregnancy .II. Correlation between Oral Hygiene and Periodontal Conditions. Acta Odontol Scand 1964 Feb; 22:121-35.

10. Ravi Kumar BP, Dudala SR, Rao AR. Kuppusamy's Socioeconomic status scale - A revision of economic parameter for 2012. International Journal of Research \& Development of Health 2013; 1(1):2-4.

11. Carlen A, Olsson J, Borjesson AC. Saliva-mediated binding in vitro and prevalence in vivo of Streptococcus mutans. Arch Oral Biol 1996; 41:35-9.

12. Berkowitz RJ, Jordan HV. Similarity of bacteriocins of Streptococcus mutans from mother and infant. Arch Oral Biol $1975 ; 20: 725-30$.

13. Kulkarni GV, Chan KH, Sandham HJ. An investigation into the use of restriction endonuclease analysis for the study of transmission of mutans streptococci. J Dent Res 1989; 68:1155-61.

14. Davey AL, Rogers AH. Multiple types of the bacterium Streptococcus mutans in the human mouth and their intrafamily transmission. Arch Oral Biol 1984; 29:453-60.

15. Caufield PW, Walker TM. Genetic diversity within Streptococcus mutans evident from chromosomal DNA restriction fragment polymorphisms. J Clin Microbiol 1989; 27:274-8.

16. Masuda N, Shimamoto T, Sobue S, Hamada S. Transmission of Streptococcus mutans in some selected families. Microbios. 1985; 44:223-32.

17. Caufield PW, Ratanapridakul K, Allen DN, Cutter GR. Plasmid containing stains of Streptococcus mutans cluster within family and racial cohorts: Implications for natural transmission. Infect Immun.1988 Dec; 56(12):3216-20.

18. Caufield PW, Wannemuehler Y, Hansen JB. Familial clustering of the Streptococcus mutans cryptic plasmid strain in a dental clinic population. Infect Immun 1982; 38(2):785-7.

19. Aaltonen AS, Tenovuo J. Association between mother-infant salivary contacts and caries resistance in children: A cohort study. Pediatr Dent 1994 March-April; 16(2):110-6.

20. Hagan T, Shah GR, Caufield PW. DNA fingerprinting for studying transmission of Streptococcus mutans. J Dent Res $1989 ; 68: 407$

21. Munshi AK. Sibling versus maternal S. mutans levels as related to dental caries. 1997 winter ; 21(2):145-50.

22. Ersin NK, Kocabas EH, Aploz AR, Uzel A. Transmission of Streptococcus mutans in a group of Turkish families. Oral Microbiol Immunol 2004; 19:408-10.

23. Hames-Kocabas EE, Ucar F, Kocatas Ersin N, Uzel A, Alpoz AR. Colonization and vertical transmission of Streptococcus mutans in Turkish children. Microbiol Res 2008; 163:168-72.

24. Doméjean S, Zhan L, DenBesten PK, Stamper J, Boyce WT, Featherstone JD. Horizontal Transmission of Mutans Streptococci in Children. J Dent Res 2010 Jan; 89(1):51-5.

25. Mattos-Graner RO, Li Y, Caufield PW, Duncan M, Smith DJ. Genotype diversity of mutans streptococci in Brazilian nursery children suggests horizontal transmission. J Clin Microbiol 2001 jun; 39(6):2313-6.

26. Kozai K, Iwai T, Miura K. Residual contamination of toothbrushes by microorganisms. ASDC J Dent Child. 1989 May-Jun; 56(3):201-4

27. Van Houte J, Green DB. Relationship between the concentration of bacteria in saliva and the colonization of teeth in humans. Infect Immun 1974 April; 9(4):624-30.

28. Warren DP, Goldschmidt MC, Thompson MB, Adler-Storthz $\mathrm{K}$, Keene HJ. The effects of toothpastes on residual microbial contamination of toothbrushes. J Am Dent Assoc 2001; 132(9):1241-5.

29. Hardie J M, Thomson PL, South RJ, March PD, Bowden GH, Mckee AS, Fillery ED, Slack GL. A longitudinal epidemiological study on dental plaque and the development of dental caries-interim results after two years. J Dent Res 1977; 56:90- 8 .

30. Mikkelsen L, Poulsen S. Microbiological studies on plaque in relation to development of dental caries in man. Caries Res $1976 ; 10: 178-88$ 